\title{
False Bean Smut Caused by Slime Mold
}

Leandro A. N. N. Agra, Claudine D. S. Seixas, and José C. Dianese, ${ }^{\dagger}$ First and third authors: Departamento de Fitopatologia, Universidade de Brasília, Campus Darcy Ribeiro, Asa Norte, 70910-900 Brasília-DF, Brasil; and second author: Embrapa Soja, Rod. Carlos João Strass, Distrito de Warta, 86001-970, Londrina-Paraná, Brasil

\begin{abstract}
Identification of the "bean smut" reported in 1998 in abstracts from two conferences was later disseminated by a Plant Disease Note; citations in books, papers, and blogs; and in several official sites, including databases curated by the United States Department of Agriculture and EmbrapaBrazil. After seeing the illustration of the syndrome in 2002, the need became clear for a review of the so-called bean smut. Field collections indicated that it is common in no-till bean and soybean farming in Brazil. Our studies revealed that the "bean smut" attributed to Ustilago sp. or

"Ustilago phaseoli" and, later, to "Microbotryum phaseoli" is not a real smut but is Physarum cinereum (Physaraceae, Physarales, Myxomycetes), sporulating superficially on leaves, stems, and pods of dry bean and soybean. To unravel this imbroglio, we produced detailed morphological documentation supported by molecular treatment. This will correct the spread and further incorporation of an error in the literature based upon mistaken taxonomical work related to a plant-associated nonpathogenic organism.
\end{abstract}

In 1998, a disease described as "bean smut" was attributed to infection by a new Ustilago sp., "Ustilago phaseoli" (Costa and Oliveira 1998), later changed to "Microbotryum phaseoli" (Oliveira et al. 2000). Both names are illegitimate, because they did not adhere to the International Code of Botanical Nomenclature required for publication of new taxa at that time (Greuter et al. 1994, 2000).

Illustrations of "bean smut" were shown by Ito et al. (2002) in a regional plant pathology meeting, which were graciously sent to the authors of this article (Fig. 1). The symptoms shown were attributed to an attack by "M. phaseoli". Our many field collections showed that the symptoms were connected to a superficial sporulation of a fungal-like organism on stems, leaves, and pods of dry bean and soybean seedlings grown in no-till farming. Here, we show that "bean smut" is not a disease but the fruiting structure of a slime mold, Physarum cinereum (Myxomycetes, Physarales, Physaraceae) on stems, leaves, and pods of dry bean and soybean seedlings grown in no-till farming.

\section{Material and Methods}

In 2015, multiple samples of dry bean and soybean were collected in areas where these crops were cultivated under no-till farming. All plant samples showed symptoms identical to those of Figure 1. A number of representative specimens were deposited in the Mycological Collection of Herbarium UB under the following access numbers: UB-Mycol. Coll. 23.241, UB-Mycol. Coll. 23.242, and UB-Mycol. 23.243.

Morphological characterization. The plant-associated organism lacked the ability to penetrate and infect the host, growing as a plasmodium that sporulated on the surface of leaves, pods, and stems. Preliminary analyses were conducted using a stereomicroscope, with semipermanent slides then prepared for light-microscopic analysis. The macroscopic characteristics of the samples were photodocumented using a Leica M 205 stereomicroscope coupled with a Leica DFC 295 digital camera connected to a microcomputer. Microscopic characteristics were observed, measured, and documented on a Leica DM 2500 light microscope, using a Leica DFC 490 camera also connected to a microcomputer. In order to view the details of the spore surface and capillitial threads, electron microscopy was performed using a scanning electron microscope (JEOL model JSM-

${ }^{\dagger}$ Corresponding author: J. C. Dianese; E-mail: jcarmine@gmail.com

Accepted for publication 18 September 2017.

(c) 2018 The American Phytopathological Society
7001F; JEOL Ltd.). Species determination was conducted according to Poulain et al. (2011).

Molecular characterization. For molecular characterization, genomic DNA was extracted following Walsh et al. (1991) as follows. In total, 10 sporocarps were placed into a $1.5-\mathrm{ml}$ tube containing two metallic beads ( $3 \mathrm{~mm}$ ) and $200 \mu \mathrm{l}$ of $5 \%$ Chellex solution. The tubes were homogenized in a Bullet Blender 24 (Next Advanced) at high speed for 3 to $5 \mathrm{~min}$. The samples were incubated at $65^{\circ} \mathrm{C}$ for $2 \mathrm{~h}$ and run through a vortex for $20 \mathrm{~s}$. The partial small ribosomal subunit was amplified with $\mathrm{PhF} 1 \mathrm{a}$ and $\mathrm{PhR} 2 \mathrm{~b}$ primers (Kamono and Fukui 2006). Polymerase chain reaction (PCR) was performed using $25 \mu \mathrm{l}$ of reaction, $0.1 \mu \mathrm{l}$ of Invitrogen DNA Taq Polymerase Platinum, $0.75 \mu \mathrm{l}$ of $\mathrm{MgCl}_{2}, 2.0 \mu \mathrm{l}$ of dNTP, $14.65 \mu \mathrm{l}$ of MilliQ $\mathrm{H}_{2} \mathrm{O}, 1 \mu \mathrm{l}$ each of primer, and $3 \mu \mathrm{l}$ of template DNA. Amplifications began with an initial step at $94^{\circ} \mathrm{C}$ for $5 \mathrm{~min}$ and 33 cycles of $94^{\circ} \mathrm{C}$ for $1 \mathrm{~min}, 58^{\circ} \mathrm{C}$ for $1 \mathrm{~min}$, and $72^{\circ} \mathrm{C}$ for $1 \mathrm{~min}$ (Ko Ko et al. 2009). Amplicons were visualized on a $1.5 \%$ agarose gel stained with ethidium bromide. The PCR products were purified using Exo-SAP according to manufacturer's instructions and sequenced at the Universidade Católica de Brasília. Sequences obtained were deposited and compared in the GenBank database (http://www.ncbi.nlm.nih.gov/).

\section{Results}

The examined materials showed abundant sporulation on stems, pods, petioles, and leaf blades of seedlings of both bean and soybean, most profusely on the adaxial surface of the leaves. Identical mature fruiting bodies were observed in all samples, which were cinereous to dark gray, becoming dark brown, and mostly containing a large number of spores. Ends of the decaying colonies showed white empty structures usually remaining on leaf and stem surface. Removal of the mass of fruiting bodies revealed intact plant epidermis, indicating that growth was essentially superficial. The plant-associated organism did not penetrate the host tissues and did not lead to tissue malformation (hyperplasia or hypertrophy), as would be expected in the case of smut fungi.

All specimens examined were shown to be covered with sporangia of a species of myxomycete, both in the case of bean and soybean. The organism was identified as P. cinereum (Batsch) Pers. (Fig. 2) that shows sporangia sessile to plasmodiocarpous, irregular in shape, subglobose or elongated, $0.30-(0.38)-0.4 \mathrm{~mm}$ wide $\times 0.4-(0.75)-1.7 \mathrm{~mm}$ long, calcareous, white to pale gray, dehiscence apical and irregular, showing internally white lime nodes bearing a dark brown spore mass; hypothallus inconspicuous; peridium simple, membranous, coated with white lime particles; columella absent; capillitium abundant connecting angular lime nodes; spores brown to dark brown, globose, verrucose, 9-11 $\mu \mathrm{m}$ diameter. 
Molecular analyses of three different specimens were based on three partial $18 \mathrm{~S}$ sequences covering more than $300 \mathrm{bp}$ and BLAST analysis using GenBank data. These results confirmed the morphological diagnosis; specifically, that the organism belongs in the phylum Amoebozoa, class Myxomycetes, order Physarales, family Physaraceae, genus Physarum. The sequences were deposited in GenBank, as follows: KT898915 = UB-Mycol. Coll. 23.243 from Phaseolus vulgaris, KT922085 = UB-Mycol. Coll. 23.241 from Glycine max, and KT922086 = UB-Mycol. Coll. 23.242 from G. max.

\section{Discussion}

Only minor physiological changes occur in plants covered by plasmodium and fruiting bodies of myxomycetes and rarely are they considered pathogens. Physarum cinereum usually fruits on living shrubs, lawns, weeds, grasses, cultivated turfgrasses, or bryophytes (Alexopoulos et al. 1996; Couch 1995; Sharnoff 1991; Stephenson and Stempen 1994; Stephenson and Studlar 1985). Although plasmodium movement onto plant seedlings located above the substrate requires energy, sporulation on leaves improves the efficiency of aeolian dispersal of myxomycetes, as suggested by Stephenson and Studlar (1985) and Kamono et al. (2009). P. cinereum involved in the false smut syndrome requires decomposing organic matter as is present in no-till conditions, where microorganisms, mostly bacteria, multiply and serve as substrate for the growth of amoeboid and plasmodial phases that precede the formation of sporangial fruiting bodies. In this process, the plasmodium accumulates nutrients and energy, shows as a watery-white or yellow slimy growth, and

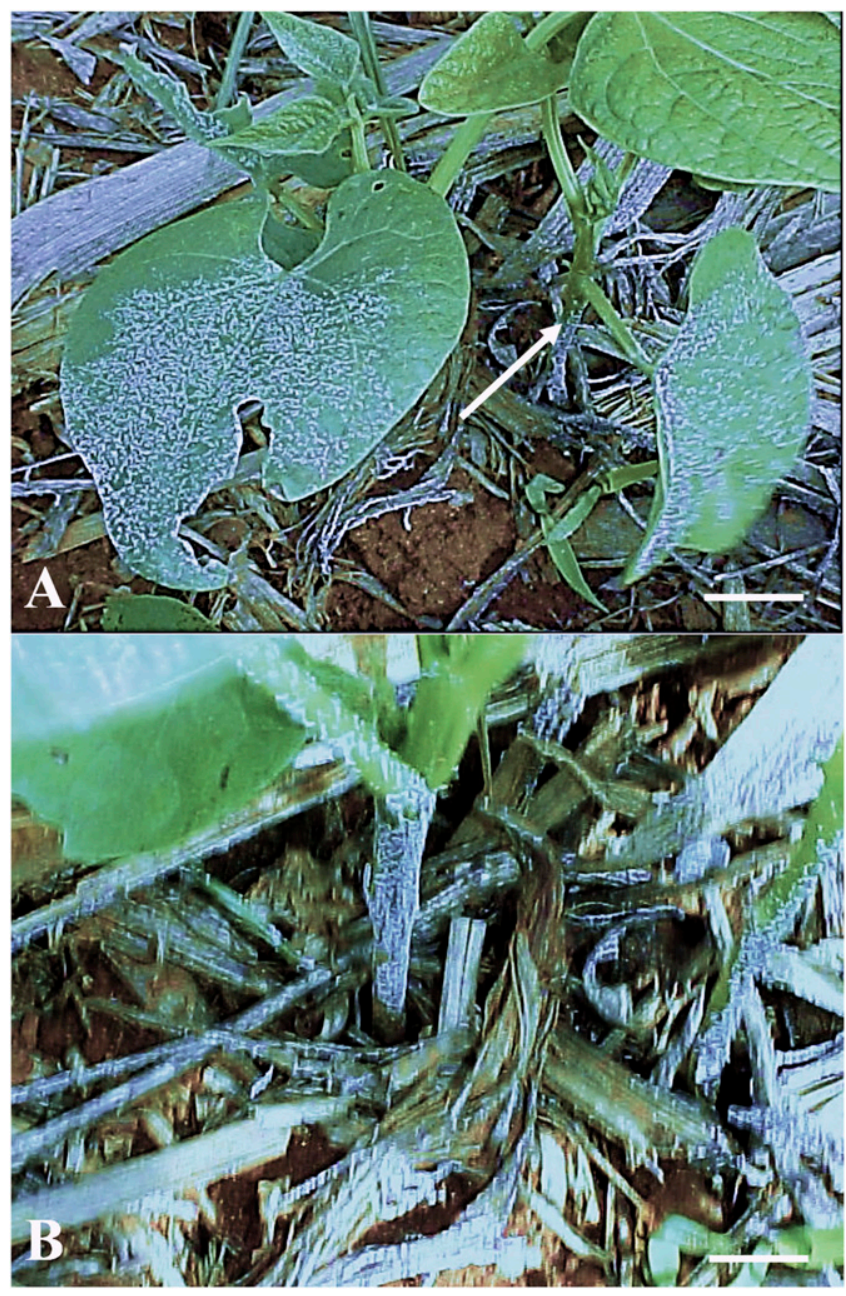

Fig. 1. Physarum cinereum on dry bean seedlings. A, Sporulation on leaf surface (left) and on the stem (arrow). B, Stem sporulation. Picture of bean smut treated as caused by Microbotryum phaseoli by Dr. Margarida Ito (Fitopatologia, IAC, Campinas, Brazil, shown here with her permission. climbs and covers the surface of bean or soybean seedlings before sporulating.

Sometimes myxomycetes are considered plant pathogens, as by Crous et al. (2000), who cite Doidge (1924) that mentions Diachea leucopodia as the cause of a severe crown rot in Medicago sativa L., a species also treated as a pathogen on strawberry in Poland and Brazil (Domingues et al. 2012; Filipowicz 1979). In Italy, Crescenzi et al. (2015) reported losses by $P$. cinereum on lettuce, endive, rocket, and celery.

The data herein confirm that the false smut caused by $P$. cinereum occurs in areas where bean and soybean are cultivated under irrigation in no-till farming in the Brazilian states of Paraná and Goiás. Although myxomycetes are known to be associated with many crops, mostly vegetables (Table 1), this is the first time it has been documented and illustrated on dry bean and soybean.

In the first note on "bean smut" (Costa and Oliveira 1998), published without illustrations, the authors proposed the new species name "U. phaseoli", ignoring the nomenclatural rules (Greuter et al. 1994). A year later, the same authors published a disease note in Plant Disease (Costa and Oliveira 1999), again without an illustration, where they reported the pathogen as Ustilago sp. "Bean smut" was described a third time in another abstract (Oliveira et al. 2000) but treated as a new Microbotryum sp., improperly designated as "M. phaseoli", ignoring Greuter et al. (2000).

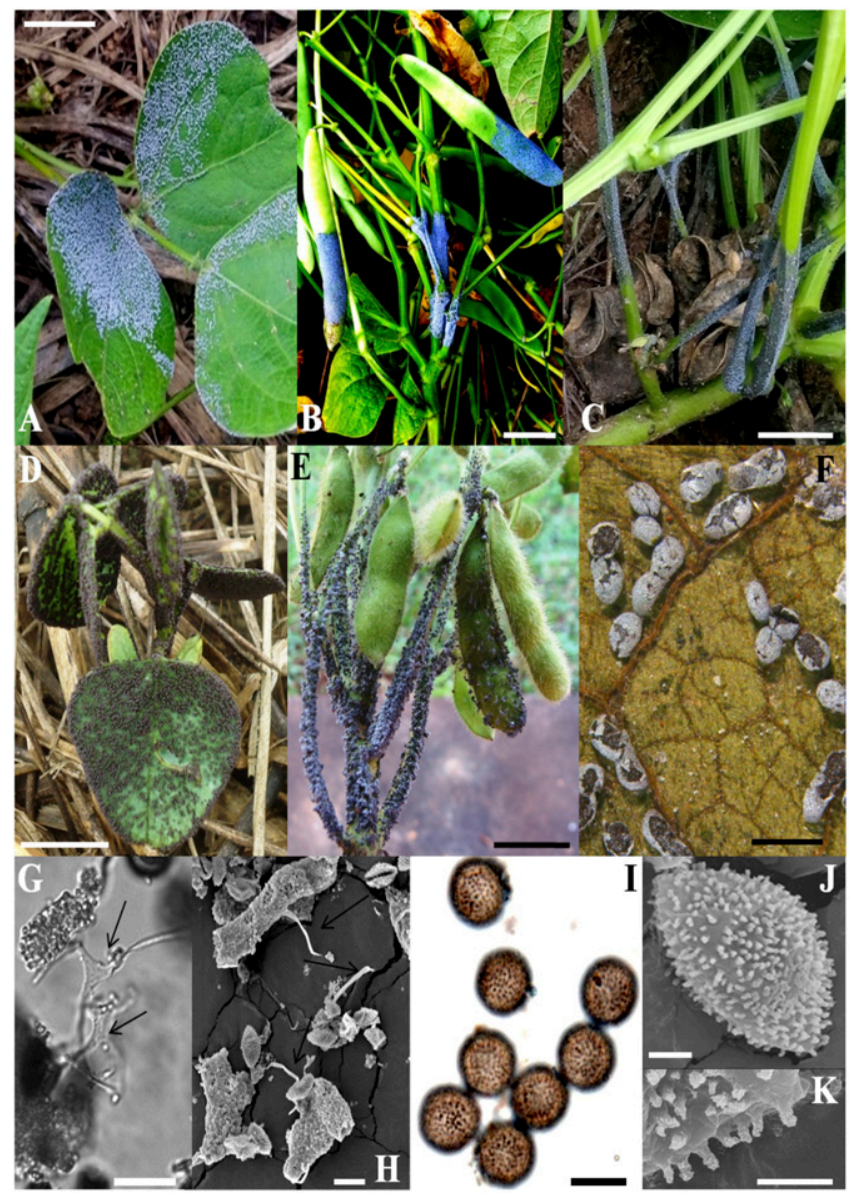

Fig. 2. Physarum cinereum on dry bean and soybean seedlings. A, Growth and sporulation on dry bean leaf surface. B, Growth and sporulation on dry bean pods and stems. C, Growth and sporulation on stems of dry bean. D, Growth and sporulation on soybean leaves. E, Growth and sporulation on soybean pods and stems. F, Mature sporocarps. G, Characteristic calcium carbonate nodes connected by capillitium threads (arrows) seen in a light microscope. $\mathrm{H}$, Clear calcium carbonate nodes interconnected by capilitium threads seen in a scanning electron microscope. I, Spores. J and K, Spore surface as seen in scanning electron microscopy. Scale bars: $A$ to $E=2 \mathrm{~cm}, \mathrm{~F}=1 \mathrm{~mm}, \mathrm{G}$ to I $=10 \mu \mathrm{m}$, and $\mathrm{J}$ and $\mathrm{K}=$ $2 \mu \mathrm{m}$. 
Table 1. Examples of Myxomycetes associated with agricultural crops

\begin{tabular}{|c|c|}
\hline Plant species (common name) & Associated myxomycete species $^{\mathbf{a}}$ \\
\hline Anacardium occidentale L. (cashew) & Physarum bogoriense $^{2}$; Diderma hemisphaericum ${ }^{6,19}$ \\
\hline Apium graveolens L. (celery) & P. cinereum $^{4,10}$ \\
\hline Brassica oleracea var. acephala DC (cabbage) & Fuligo septica ${ }^{2}$ \\
\hline Beta vulgaris L. var. saccharifera (sugarbeet) & P. cinereum $^{13}$ \\
\hline Camellia sinensis (L.) Kuntze (tea) & Ceratiomyxa sphaerosperma ${ }^{8}$ P. laevisporum ${ }^{8}$ \\
\hline Carica papaya L. (papaya) & 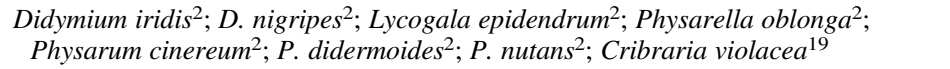 \\
\hline Chicorium endive L. (endive) & P. cinereum $^{10}$ \\
\hline Citrullus lanatus (Thumb.) Matsum. \& Nakai (watermelon) & F. septica ${ }^{2}$ \\
\hline Coffea arabica L. (coffee) & 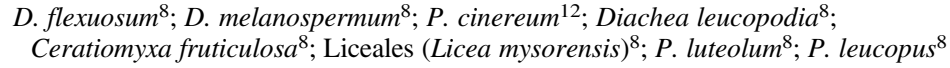 \\
\hline Cucumis melo L. var. cimarron (muskmelon) & F. gyrosa $^{13} ;$ P. cinereum $^{6,19}$ \\
\hline Eryngium foetidum L. (coriander) & F. septica ${ }^{2}$ \\
\hline Eruca sativa L. (rocket) & P. cinereum $^{10}$ \\
\hline Fragraria $\times$ ananassa Duchesne (strawberry) & D. leucopodia ${ }^{4,13,17} ;$ Fuligo septica $^{17} ;$ Mucilago spongiosa ${ }^{17} ; P$. cinerum $^{1,17}$ \\
\hline Ginkgo biloba L. (ginkgo) & P. nigripodium ${ }^{11}$ \\
\hline Gossypium hirsutum L. (cotton) & P. nutans ${ }^{8} ;$ Didymium saturnus ${ }^{8}$ \\
\hline Ipomea batatas (sweet potato) & F. septica ${ }^{13} ;$ Stemonitis herbatica ${ }^{13} ; P$. cinereum $^{17}$ \\
\hline Lactuca sativa L. (lettuce) & P. cinereum $^{17,10} ; F$. septica $;$ Diachea sp. $^{2}$ \\
\hline Manihot esculenta Crantz. (cassava) & Craterium leucocephalum $^{2} ;$ Physarella oblonga $^{2}$ \\
\hline Medicavo sativa L. (alfalfa) & Physarum cinereum ${ }^{17} ;$ Diachea leucopodia ${ }^{16}$ \\
\hline Morus sp. (mulberry) & Didymium clavus ${ }^{9}$ \\
\hline Musa paradisiaca L. (banana) & P. nucleatum ${ }^{8} ;$ P. reniforme ${ }^{8} ;$ P. sessile ${ }^{8} ;$ Hemitrichia serpula ${ }^{8} ;$ Physarella oblonga $^{2}$ \\
\hline Nicotiana rustica L. (mapacho/thuoc lao) & S. herbatica ${ }^{14}$ \\
\hline Paullinia cupana Kunth (guarana) & Stemonitis sp. ${ }^{2}$ \\
\hline Persea americana Mill. (avocado) & Physarum didermoides ${ }^{2}$ \\
\hline Petroselinum crispum (Mill.) Fuss (parsley) & Diachea sp. $^{2}$ \\
\hline Phsaeolus vulgaris L. (dry bean) & Diachea leucopodia ${ }^{17}$ \\
\hline Raphanus sativus L. (radish) & Physarum sp..$^{13}$ \\
\hline Saccharum officinarum L. (sugar cane) & 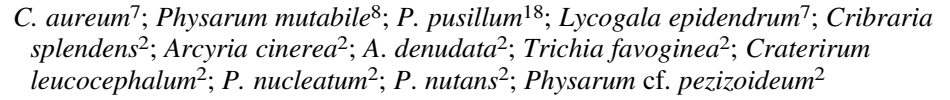 \\
\hline Salvia officinalis L. (sage) & Diderma hemispharicum 8 \\
\hline Solanum melongea L. (eggplant) & Arcyria insignis $^{2} ;$ Didymium iridis $^{2}$ \\
\hline S. tuberosum L. (potato) & D. quitense 8 \\
\hline Theobroma cacao L. (cocoa) & Stemonitis sp. ${ }^{15}$; Stemonitis axifera ${ }^{7} ;$ P. nutans ${ }^{7}$ \\
\hline Vignia unguiculada subsp. sesquipedalis (L.)Verdc. (yard long bean) & P. cinereum $^{3}$ \\
\hline Vitis L. sp. (grape) & Physarum sp. ${ }^{13}$ \\
\hline Zea mays L. (corn) & $\begin{array}{l}\text { D. } \text { iridis }^{17} ; \text { D. saturnus } \\
\text { javanicum } \\
\text { javerichaena vermicularis }\end{array}$ \\
\hline
\end{tabular}

a Countries and references: ${ }^{1}$ Australia (Cook and Dubé 1989), ${ }^{2}$ Brazil (Domingues et al. 2012; Mendes et al. 1998; Silva and Bezerra 2005; Silva et al. 2008), ${ }^{3}$ Brunei (Peregrine and Ahmad 1982), ${ }^{4}$ Canada (Conners 1967), ${ }^{5}$ Colombia (Chardon and Toro 1930), ${ }^{6}$ Cuba (Urtiaga 1986), ${ }^{7}$ Dominican Republic (Ciferri 1961), ${ }^{8}$ India (Ranade et al. 2012; Sarbhoy et al. 1971), ${ }^{9}$ Israel (Binyamini 1991), ${ }^{10}$ Italy (Crescenzi et al. 2015), ${ }^{11}$ Japan (Nannenga-Bremekamp and Yamamoto 1987), ${ }^{12}$ Kenya (Nattrass 1961), ${ }^{13}$ Korea (Cho and Shin 2004; Kim et al. 2007, 2009, Lee et al. 2008), ${ }^{14}$ Malawi (Peregrine and Siddiqi 1972), ${ }^{15}$ Papua New Guinea (Shaw 1984), ${ }^{16}$ South Africa (Crous et al. 2000), ${ }^{17}$ United States of America (Farr and Rossman 2017), ${ }^{18}$ Venezuela (Urtiaga 1986), and ${ }^{19}$ West Indies (Minter et al. 2001).

Following Costa and Oliveira (1999), the mistaken information became known in the Brazilian literature, mainly after the inclusion of "bean smut" (Ustilago sp.) in the United States Department of Agriculture Fungal Database (Farr and Rossman 2017). Citing Oliveira et al. (2000), the Embrapa Database of Fungi on Plants in Brazil (Mendes and Urben 2017) included "M. phaseoli" as the agent of "bean smut".

Thus, the mistaken report is present in important databases in the United States (Farr and Rossman 2017) and Brazil (Mendes and Urben 2017); was spread through conference abstracts (Ito et al. 2002), papers (Paula-Junior et al. 2004), book chapters (Dourado-Neto and Fancelli 2000; Vieira et al. 2006), extension booklets (Ito and Stein 2007; Posse et al. 2010; Sartorato 2003, 2007), a blog report (Ferreira 2015), websites (http://unifeijao.com.br/site2013/doencas_feijao.php? txt=7, http://www.ebah.com.br/content/ABAAABYMgAC/trabalhosobre-pragas-doencas-no-feijoeiro, http://agroready.blogspot.com. br/2010/09/doencas-fungicas-carvao.html, and https://fitopatologia1. blogspot.com.br/2010/07/revisao-de-literatura-de-feijao.html); and was cited in theses and dissertations (Costa 2007; Miranda-Filho 2010; Silva 2011).

Thus, with this article, we hope to correct this misidentification and eradicate the use of the illegitimate fungal names "Ustilago phaseoli" and "Microbotryum phaseoli" in plant-pathological literature.

\section{Acknowledgments}

We thank M. Lobo (EMBRAPA-Arroz e Feijão) for samples collected in Goiás; J. R. Menezes for field pictures of bean showing false smut; CAPES/Ministry of Education-Brazil for a doctorate fellowship to the first author Leandro Agra; R. Neil Gerard Miller for review of the manuscript and English corrections; and CNPQ/Ministry of Science, Technology and Innovation-PPBIO/Cerrado for research grant number PPBIO 457455/2012-8 to J. C. Dianese.

\section{Literature Cited}

Alexopoulos, C. J., Mims, C. W., and Blackwell, M. 1996. Introductory Mycology, 4th ed. Wiley, New York.

Binyamini, N. 1991. Myxomycetes from Israel III. Trans. Mycol. Soc. Jpn. 32. 485-493.

Chardon, C. E., and Toro, R. A. 1930. Mycological explorations of Colombia. J. Dep. Agric. P. R. 14:195-369.

Cho, W. D., and Shin, H. D. 2004. List of Plant Diseases in Korea, 4th ed. Korean Society of Plant Pathology, Suwon, Korea Republic.

Ciferri, R. 1961. Mycoflora Domingensis Integrata. Quaderno del Laboratorio Crittogamico del Istituto Botanico dell'Università di Pavia. 19:1-539

Conners, I. L. 1967. An Annotated Index of Plant Diseases in Canada and Fungi Recorded on Plants in Alaska, Canada and Greenland. Canada Dep. Agric. Publ. 1251.

Cook, R. P., and Dubé, A. J. 1989. Host-Pathogen Index of Plant Diseases in South Australia. South Australian Department of Agriculture, Adelaide, Australia. 
Costa, G. R. 2007. Estratégias para o manejo integrado da mela do feijoeiro causada por Thanatephorus cucumeris. DSc. thesis, Universidade de Brasília, Brasília, Brasil.

Costa, J. L. S., and Oliveira, V. C. 1998. Pathogenicity of Ustilago sp. on dry beans. Page 59 in: Ann. Sixth Int. Mycol.. Congr. (IMC6), Jerusalem, TelAviv, Israel.

Costa, J. L. S., and Oliveira, V. C. 1999. Occurrence of smut caused by a Ustilago sp. on dry beans. Plant Dis. 83:486.

Couch, H. B. 1995. Diseases of Turfgrass, 3rd ed. Krieger Publishing Company, Malabar, FL.

Crescenzi, A., Rana, G. L., Fanigliulo, A., Lahoz, E., and Carrieri, R. 2015. First report of Physarum cinereum on lettuce, rocket, endive, and celery in Italy. Plant Dis. 99:1272.

Crous, P. W., Phillips, A. J. L., and Baxter, A. P. 2000. Phytopathogenic Fungi from South Africa. University of Stellenbosch, Department of Plant Pathology Press, Stellenbosch, South Africa.

Doidge, E. M. 1924. A preliminary checklist of plant diseases occurring in South Africa. Memoir Bot. S. Afr. 6:1-56.

Domingues, R. J., Tofoli, J. G., Ferrari, J. T., and Nogueira, E. M. C. 2012. Primeiro registro de ocorrência de Diachea leucopodia (Bull.) Rostaf. (1874) em cultivo de morangueiro no Brasil. Instituto Biológico, Documento Técnico 15, São Paulo, SP, Brasil.

Dourado-Neto, D., and Fancelli, A. L. 2000. Implantação da cultura. Pages 87-133 in: Produção de Feijão. D. Dourado-Neto and A. L. Fancelli, eds. Editora Agropecuária, Guaíba, Rio Grande so Sul, Brazil.

Farr, D. F., and Rossman, A. Y. 2017. Fungal Databases, U.S. National Fungus Collections. Online publication. United States Department of AgricultureAgricultural Research Service. https://nt.ars-grin.gov/fungaldatabases/

Ferreira, B. S. 2015. Melhoramento de Plantas: Revisão de Literatura Sobre a Cultura do Feijão Phaseolus vulgaris L. Online publication. http://fitopatologial blogspot. com.br/2010/07/revisao-de-literatura-de-feijao.html

Filipowicz, A. 1979. Sluzowce (Myxomycetes) patogenami truskawek [The slime molds (Myxomycetes) as pathogens of strawberries]. Ochr. Rosl. (Wyd. 4) 23:15-16.

Greuter, W., Barrie, F. R., Burdet, H. M., Chaloner, W. G., Demoulin, V., Hawksworth, D. L., Jørgensen, P. M., Nicolson, D. H., Silva, P. C., Trehane, P., and McNeil, J. 1994. International Code of Botanical Nomenclature (Tokyo Code). Online publication. http://www.bgbm.fu-berlin.de/iapt/nomenclature/code/ tokyo-e/Contents.htm

Greuter, W., Barrie, F. R., Burdet, H. M., Demoulin, V., Filgueiras, T. S., Nicolson, D. H., Silva, P. C., Skog, G. E., Trehane, P., Turland, N. J., and Hawksworth, D. L. 2000. International Code of Botanical Nomenclature (ST LOUIS CODE). Online publication. http://www.bgbm.org/iapt/nomenclature/ code/SaintLouis/0000St.Luistitle.htm

Ito, M. F., Castro, J. L., Wutke, E. B., Martins, A. L. M. M., and Ito, M. A. 2002. Microbotryum phaseoli em feijoeiro, no Estado de São Paulo. Summa Phytopathol. 28:94.

Ito, M. F., and Stein, P. C. 2007. VI Seminário sobre pragas, doenças e plantas daninhas do feijoeiro. Documentos IAC, 79, Campinas, SP, Brasil.

Kamono, A., and Fukui, M. 2006. Rapid PCR-based method for detection and differentiation of Didymiaceae and Physaraceae (myxomycetes) in environmental samples. J. Microbiol. Methods 67:496-506.

Kamono, A., Kojima, H., Matsumoto, J., Kawamura, K., and Fukui, M. 2009. Airborne myxomycete spores: Detection using molecular techniques. Naturwissenschaften 96:147-151.

Kim, W. G., Choi, H. W., Hong, S. K., Lee, Y. K., and Lee, S. H. 2009. Occurrence of Fuligo gyrosa causing slime mold of oriental melon. Mycobiology 37:238-239.

Kim, W. G., Lee, S. Y., and Cho, W. D. 2007. Two species of Myxomycetes causing slime mold of sweet potato. Mycobiology 35:97-99.

Ko Ko, T. W., Stephenson, S. L., Jeewon, R., Lumyong, S., and Hyde, K. D. 2009. Molecular diversity of Myxomycetes associated with decaying wood and forest floor leaf litter. Mycologia 101:592-598.

Lee, J. H., Han, K. S., Bae, D. W., Kim, D. K., and Kim, H. K. 2008. Identification of Diachea leucopodia on strawberry from greenhouse in Korea. Mycobiology 36:143-147.
Mendes, M. A. S., Silva, V. L., Dianese, J. C., Ferreira, J. A. S. V., Santos, C. E. N., Gomes Neto, E., Urben, A. F., and Castro, C. 1998. Fungos em plantas no Brasil. EMBRAPA-SPI, Brasília, Brasil.

Mendes, M. A. S., and Urben, A. F. 2017. Fungos relatados em plantas no Brasil, Laboratório de Quarentena Vegetal. Embrapa Recursos Genéticos e Biotecnologia, Brasília, DF, Brasil. Online publication. http://pragawall.cenargen.embrapa.br/ aiqweb/michtml/fichafg.asp?id=2089

Minter, D. W., Rodríguez-Hernández, M., and Mena-Portales, J. 2001. Fungi of the Caribbean: An Annotated Checklist. PDMS Publishing, London.

Miranda-Filho, R. J. 2010. Etiologia, Epidemiologia e Fisiologia da Murcha de Curtobacetrium. D.Sc. thesis, Universidade de Brasília, Brasília, Brasil.

Nannenga-Bremekamp, N. E., and Yamamoto, Y. 1987. Additions to the Myxomycetes of Japan III. Proc. Kon. Ned. Akad. Wetensch. 90:311-349.

Nattrass, R. M. 1961. Host lists of Kenya fungi and bacteria. Mycol. Pap. 81:1-46.

Oliveira, V. C., Falcão, R., and Costa, J. L. S. 2000. Comparação fotomicrográfica de teliósporos dos agentes causais do carvão do feijoeiro e do milho. Fitopatol. Bras. 25:403.

Paula-Junior, T. J., Vieira, R. F., and Araújo, G. A. A. 2004. Manejo integrado de doenças do feijoeiro de plantio direto. Pages 11-44 in: Manejo integrado: Integração agricultura-pecuária. L. Zambolim, A. A. Silva, and E. L. Agnes, eds. UFV, Viçosa, Brazil.

Peregrine, W. T. H., and Ahmad, K. B. 1982. Brunei: A first annotated list of plant diseases and associated organisms. Phytopathol. Pap. 27:1-87.

Peregrine, W. T. H., and Siddiqi, M. A. 1972. A revised and annotated list of plant diseases in Malawi. Phytopathol. Pap. 16:1-51.

Poulain, M., Meyer, M., and Bozonnet, J. 2011. Les Myxomycètes. Fédération Mycologique et Botanique Dauphiné-Savoie, Sévrier, France.

Posse, S. C. P., Riva-Souza, E. M., Silva, G. M., Fasolo, L. M., Silva, M. B., and Rocha, M. A. M. 2010. Informações técnicas para o cultivo do feijoeiro-comum na região central-brasileira: 2009-2011. Online publication. INCAPER. http://www.cnpaf. embrapa.br/transferencia/informacoestecnicas/19ctcbf/19ctcbf_livrocompleto.pdf

Ranade, V. D., Korade, S. T., Jagtap, A. V., and Ranadive, K. R. 2012. Checklist of Myxomycetes from India. Mycosphere 3:358-390.

Sarbhoy, A. K., Lal, G., and Varshney, J. L. 1971. Fungi of India (1967-71). Navyug Traders, New Delhi, India.

Sartorato, A. 2003. Pages 8-11 in: Feijão: Principais Doenças. Correio Agrícola (Bayer Crop Science), São Paulo, Brasil.

Sartorato, A. 2007. Desafios no controle de doenças na cultura do feijoeiro na região Centro-Oeste. Pages $15-17$ in VI Seminário sobre pragas, doenças e plantas daninhas do feijoeiro. Documentos IAC, 79, Campinas, SP, Brasil. Online publication. http://www.iac.sp.gov.br/publicacoes/publicacoes_online/ pdf/doc79.pdf

Sharnoff, S. D. 1991. Beauties from a beast: woodland Jekyll and Hydes. Smithsonian 22:98-103.

Shaw, D. E. 1984. Microorganisms in Papua New Guinea. Research Bulletin No. 33. Department of Primary Industry, Port Moresby, New Guinea.

Silva, A. A. 2011. Aplicação de leite isolado e associado a fungicidas e adjuvantes no controle do oídio na cultura do feijão. M.Sc. dissertation, Universidade Estadual de Ponta Grossa, Ponta Grossa, Paraná, Brazil.

Silva, S., and Bezerra, J. L. 2005. Ocorrência de Fuligo septica em alface e coentro de caboclo. Fitopatol. Bras. 30:439.

Silva, S. G., Ferreira, I. C. M., and Bitencourt, N. V. 2008. Novos hospedeiros de Fuligo septica no Estado do Maranhão. Summa Phytopathol. 34:97.

Stephenson, S. L., and Stempen, H. 1994. Myxomycetes: A Handbook of Slime Molds. Timber Press, Portland, OR.

Stephenson, S. L., and Studlar, S. M. 1985. Myxomycetes fruiting upon bryophytes: coincidence or preference? J. Bryol. 13:537-548.

Urtiaga, R. 1986. Indice de enfermedades en plantas de Venezuela y Cuba. Impresos Nuevo Siglo. S.R.L., Barquisimeto, Venezuela.

Vieira, C., Paula-Junior, T. J., and Borém, A. 2006. Feijão, 2nd ed. Editora UFV, Viçosa, Minas Gerais, Brazil.

Walsh, P. S., Metzger, D. A., and Higuchi, R. 1991. Chelex 100 as a medium for simple extraction of DNA for PCR-based typing from forensic material. Biotechniques 10:506-513. 